\title{
産学官連携に対する現状と課題 学の視点から-
}

大野英男

科学技術政策研究所の調查によると、日本企 業が我が国の大学に支出している金額は海外

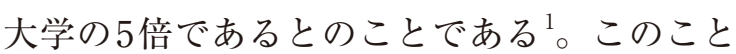
から伺えるように、大学はこれまでも産学連携 で一定の役割を果たしてきた。しかし、ここに きて、経済再生へ向けたイノベーション拠点と して大学が一層強力に機能すべきであるとの 声が高まっている。大学がこれまでに担ってき た教育や研究に加えて、産学官のイノベーショ ン拠点機能への期待に応えていくためには何 を考えておくべきか、学の視点から述べたい。

第一に、産学連携は教育や基礎研究と時間ス ケールが異なる点である。このため、産学連携 組織を教育や基礎的研究を担う組織と別にす ることがのぞましい。国際的な競争環境の中で 産学連携を成功させるには、事業が要求する時 間で成果を出す必要がある。これは必ずしも教 育や研究の時間と整合するものではない。別組 織とすることにより組織の目的・目標が明確と なり、運営が機動的にでき、責任も明確になる。 検討されているCenter of Innovationもそのよ うな試みと位置づけることができよう。

次に、教員の機能分化やそれに伴う評価の指 標設定が重要となる。従来、大学教員は皆同じ 役割を担うという考え方が主流であった。しか し、国際的競争力を持つ教育、世界をリードす る研究、産業に大きな貢献をする産学官の連携、 さらにはそれらの運営までを、教員全員に一様 に要求するのは難しい。ただでさえ運営費交付
金の減少もあって、教員は多忙を極め、一人あ たりの論文数も減少傾向にある。いま以上に一 人の教員がやるべきことを一様に増やしては いけない。新たな事業には新たなりソースの手 当が必要なことは言うまでもないが、従来の人 的リソースの上に新たな事業を構築するので あれば、構成員が納得し誇りを持って取り組め るようにするべきである。そのためには、大学 は教育が基本にあることを踏まえつつ、産学官 連携を含めた多様な役割を教員が流動的に果 たせる制度の構築や運営が必要である。

大学で創造される知を、産学官連携へと橋渡 しするしくみも重要となる。多くの教員になじ みのある科学研究費補助金に、産学官連携に特 化した種目を設定するのも一案である。また、 産学官のコーディネートを支援する要員の配 置も考えなければならない。現状では、たとえ やりくりしてコーディネータを手当てしたと しても財政的な裏付けがないため、身分が不安 定になりがちである。キャリアパスを含め大学 全体を視野に入れた制度設計が求められる。 コーディネータの充実により、教員が教育・研 究や産学官連携活動に割ける時間も確保でき ることになるであろう。

知財に関しては、大学の保有特許を利活用し て収益をあげる従来のやり方に加えて、大学の 特許によって、企業が安心して共同開発に従事 することができるという面に着目したい。特許 を保有していることで産学官連携が一層進むの 
であれば、必ずしも特許で収益をあげる必要は ない。また、過去に取得した特許を新たなプロ ジェクトで維持できない点も見直すべきであろ う。重要な特許の上に構築される事業であれば、 特許を維持する費用の支出は矛盾がない。大学 が特許を保有する意義を整理して、個々の事情 にあった運用形態を選べるようにしたい。

海外企業との産学連携についても考え方を 整理しておく必要がある。税金で運営されてい る国立大学法人であっても、グローバル化した 世界で活動する以上、国外の企業が費用を負担 する産学官連携は、企業の納税の状況により費 用負担の度合いは変わるにしても、国内企業の 場合と同様に大いに推進すべきであろう。そも そも、国外企業も大いに魅力を感じる産学連携 のもととなる成果があるから、グローバル化し た世界でトップレベルの大学として認められ るのである。これらの活動を広い意味での国の 富とする考え方や仕組みの構築が急がれる。国 内外の企業が参画する産学官連携が進めば、世 界を相手に活躍する学生や社会人を育成し、鍛 錬するすばらしい環境となるであろう。ただし、 教員にのみ一層の負担を求めてこれを進めて も持続的なものにはならない。グローバルな産 学連携環境の構築には、契約を含めた様々な交 渉や手続き、研究員の受け入れなどを担当する 人材や部署の育成と充実が必要である。

経済再生へ向けたイノベーションの期待を 背に、大学における産学官連携は、新た段階を

\section{PROFILE}

大野英男

(おおの ひでお)

日本学術会議連携会員、東北大学電

気通信研究所教授

専門 : 電子工学、スピントロニクス
迎えようとしている。いくつもの成功例を早期 に出し、それらがロールモデルとなって、さら に、大きな成果へとつなげるサイクルが求めら れている。イノベーションに向けて大学の潜在 力は大きい。潜在力を顕在化し持続する本当の 力としていくために、新たな大学運営が求めら れている。特に、東日本大震災の被災地域では これは切実な願いである。

\section{参考文献}

1. 科学技術政策研究所リポジトリhttp://hdl.handle. net/11035/1141. 